\title{
Looking Beyond Processing of Auditory Stimuli - Could a More Generalised Problem with Processing Skills Contribute to Poor Learning and Listening?
}

\author{
Iyngaran Vanniasegaram* \\ Department of Audio-Vestibular Medicine, UK
}

Submission: July 13, 2017; Published: July 27, 2017

*Corresponding author: Iyngaran Vanniasegaram, Department of Audio-Vestibular Medicine, Harold Wood Clinic, 24 Gubbins Lane, Essex RM3 0QA, UK, Tel: 03003001658; Email: iynga.vanniasegaram@nhs.net

\section{Introduction}

Children who present to the audiology clinic with normal peripheral hearing but poor response to speech in noise or paired tones may have an auditory processing disorder (APD) [1].

Hearing involves a sequence of responses from ear to brain, including transfer of the acoustic stimulus across the ear, transduction of sound into neural impulses in the inner ear and transmission of the neural impulses to the brain. The interpretation of these impulses in the brain creates the perception and understanding of this information.

In APD inefficient processing occurs in the Central Nervous System, despite efficient sensory information production in the ear. If information processing is a generalised skill, rather than sense specific, then processing of one type of information, such as auditory information, is unlikely to be completely independent of the processing of other types of sensory information, such as vision, touch and awareness of body movement. More complex functions using sensory information, such as attention, modulating emotions, impulse control, special reasoning tasks, planning and scheduling, may also be compromised.

Children presenting in this way can have variable levels of dysfunction across a range of skills, such as learning, movement and balance control, attention and social interaction, and show features associated with a range of other conditions, such as Attention Deficit Hyperactivity Disorder (ADHD), dyslexia, dyspraxia, language delay, hyperacuscis or social communication difficulties [2-9]. These children present to a range of professionals: audiologists, psychologists, speech therapists, physical therapists and paediatricians.

This paper aims to provide a better understanding of the range of conditions which may co-exist, have a common fundamental dysfunction or be different presentations of a single disorder. We review current knowledge and strategies being used. A co-ordinated holistic approach to the management of these children is suggested, to consider all areas, beyond that of the professional to whom they present.

\section{Clinical Presentation}

Children with APD can present with difficulty in following oral instructions, listening, hearing in background noise, or with learning. It commonly presents in school age children. Some children have excessive reactions to sounds, with symptoms of hyperacusis (marked intolerance of noise) $[10,11]$.

It is worth noting that children with identifiable peripheral hearing loss may also have co-existing APD. APD difficulties may predominate, or may co-exist with features of processing difficulties in other modalities [12-14]. As APD is associated with rare but potentially serious medical conditions these should be excluded [15]. Even with a strong history of APD, test batteries can be negative, suggesting other factors are involved. While the predominant area of difficulty varies, when processing difficulties are identified in one modality, difficulties in other modalities, such as postural control, literacy, attention control and communication, need to be considered.

Poor postural control may present with dyspraxic or Developmental Coordination Disorder (DCD) symptoms, with clumsiness in gross, fine or combined motor functions [16-19]. Many diagnostic terms have been applied to these difficulties [20]. DSM IV criteria for DCD suggest marked impairment of motor coordination, interfering with daily life, not due to a general medical condition. It may be a motor learning disorder [21].

Literacy difficulties occur with symptoms of dyslexia, commonly considered a phonological awareness problem [22]. The basis of phonological awareness is the consistent association 


\section{Global Journal of Otolaryngology}

of sound and text, which is disrupted by inconsistent processing of text information [23].

When these basic tasks require excess effort to accomplish the children become mentally tired. This manifests as difficulty staying focused, and presents as ADHD symptoms [24,25], with associated behavioural and emotional variability.

Auditory and speech processing difficulties can manifest as unusual patterns of communication. It is not suggested that the criteria for formal diagnosis of the above problems would be satisfied, but that features of them exist and have a compounding effect on the child's functional performance.

The conditions mentioned may be hereditary [26-30], so either or both parents may have similar difficulties to their child. This can interfere with their ability to attend appointments and help with the child's management.

\section{Explanation of the Presenting Problems in Relation to Processing Difficulties}

For precise control of movement, rapid and accurate information from our somatosensory, visual and vestibular systems is required. If this information is present, but processed slowly, then control of posture (especially standing still or accurate movements) becomes difficult. Fine movement coordination may also be less accurate and consistent. Marked difficulties produce a DCD picture [31].

Poor fine control of posture and eye movement reduces the ability to process rows of similar small shapes (such as letters on a page) accurately and consistently. This makes decoding text difficult and can lead to dyslexic difficulties [32-35].

Inattentiveness and difficulty being still are core ADHD symptoms. With poor processing skills more effort is required to deal with information, producing mental tiredness and making continued concentration difficult. This can be seen as difficulty sustaining attention [36,37]. Tiredness and sleepiness are both associated with increased postural sway and movement [38-40].

In normal circumstances small movements are used to assess our postural control and remaining motionless will create anxiety that requires movement to relieve. Reduced use of the information required for postural control produces more sway and compensatory increased muscle tension. More areas of brain activity can be recorded at these times [41,42] and more attention is required [43]. People with anxiety disorders have more postural sway under normal conditions [44], and patients with vestibular disease and unsteadiness report feeling detached from their surroundings, depersonalization [45], possibly due to sensory mismatch, affecting concentration [46]. A combination of poor postural control and anxiety created by the need to move makes sitting still hard for these children.

Specific Language Impairment (SLI) may be considered at three interacting levels [47]: Central cognitive production and understanding of language, processing this information and or omotor function to produce speech. Hence processing difficulties can also be a factor in language disorders [48,49]. Slow processing can lead slow response to questions, which may be interpreted as showing low cognitive ability.

\section{Evidence for Variability in Speed of Sensory Processing}

The ability to distinguish similar sensory inputs is decreased in children with dyslexic difficulties. This has been shown in skin point-to-point separation sensitivity, visual point to point discrimination, and discrimination of similar sounds [50-53]. Recently similar findings have been reported in persons with Aspergers syndrome [54].

These problems may arise from processing deficits within individual systems [55-57], but the cerebellum has a central role in processing, and could be the connecting factor in sensory processing problems [58-66]. The question of whether this is cause, effect or simply co-occurrence (i.e. cerebellar abnormalities and sensory processing abnormalities may have the same cause but may not be causally related themselves) has also been raised and has caused much debate [67-72]. This may explain the feeling that many people working in this area have that dyslexia, dyspraxia, ADHD, APD and SLI, rather than being distinct entities, may be the variable presentations of processing difficulties with different dominant problems and that the experience of the professional whose advice is sought may influence the diagnosis given [73].

Suggestions for A Holistic Approach To The Management of These Children

Most specialist clinics cannot comprehensively rule out all the diagnoses mentioned above, but a combination of clinical awareness and targeted questions will allow identification of children who may benefit from more in depth testing. A multidisciplinary approach would be beneficial

The history is very important, and asking targeted questions about literacy, postural control, attention control, speech and communication, will give a clear picture of the areas of difficulty (Figure 1).

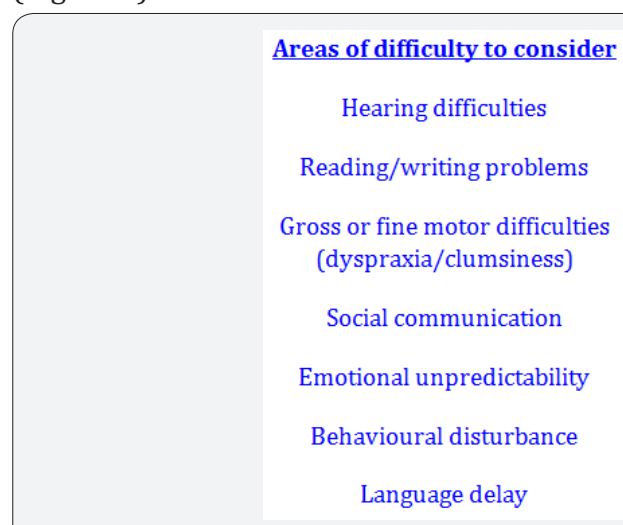

Figure 1: Areas of difficulty to consider. 
In addition to the usual examination, soft neurological signs may also be sought. There are examination systems that are reliable, though the predictability of the findings is disputed [74-80]. These are often seen in DCD, but are common in many children with processing difficulties [81-85]. These require experience to attain the frame of reference to distinguish them from the "usual" reactions.

\section{Investigations to help to focus on the problem areas for the child}

Speech-in-noise test; Diagnostic test batteries for APD exist, [86] but the speech-in-noise test can give an insight into problems associated with noisy classrooms, known to be a problem for children with learning problems [87]. -Reading/ writing skills (dyslexia screening tests); these usually test against the population average, so a bright child may get a good score, despite having dyslexic problems $[88,89]$.

An awareness of the child's intelligence or IQ; this is relevant to both the child's ability to cope with poor processing (better if they are bright), and also that less bright children may not have the capacity to deal with information, even if it is processed well.

Questionnaires for ADHD symptoms (short version Connor's rating scale or SNAP IV [90]) have been developed from the diagnostic criteria of DSMIV; these can be used to give an impression of the presence of these symptoms, though they are not diagnostic, due to their brevity and non-pervasive testing environment.

While there are formal ways to assess for dyspraxic difficulties (such as Movement ABC [91]), the history alone is often strongly suggestive as the children are often felt to be clumsy, to often spill or bump into things, and do not enjoy team sports.

\section{Management}

It is worth noting that while the management options here are being used in practice the value of the research evidence that exists has been disputed.

\section{General points that may be beneficial whichever areas of difficulty the child has}

a) Seating in class, with attention given to how the teaching staff are seen and heard.

b) Decrease background noise, using sound field and FM systems, where available [92]

c) Structured approach to learning, including pre "teaching".

d) Small amounts of information, rather than given in bulk.

e) Allowance for slow speed of response and copying speed (pre-printed sheets). f) Excess unstructured homework may be counterproductive (due to tiredness).

g) Loss of confidence has a negative feedback effect.

h) Computer based educational programmers (evidence for efficacy is lacking) $[93,94]$.

\section{General exercise requirements}

Exercise often acts as a release of the tension created by being still. Physical exercise is associated with calmer and less disruptive behaviour in children with ADHD, as well as with better behavioural compliance and academic performance in the general population [95-99]. The teacher, instructor or coach needs to know the child's problems and make allowances, especially for those with DCD difficulties. The child should not be put in situations they are not ready for, where they may be humiliated. Each of the medication and therapy portions of this review are brief overviews of complex subjects, and evidence for each is debated.

\section{Nutrition}

Omega 3 fatty acid supplements: alleviate ADHD-related symptoms in some children [100,101]. they can produce improvements in behaviour, reading and spelling skills in children with DCD [102]. They may improve mood disorders, as well as other skills $[103,104]$ while negligible side effects were noted.

Food additives may contribute to behavioral disorders, especially to hyperactivity. Other than additives, milk, wheat and eggs have been found to be the commonest diet allergens, leading to suggestions of exclusion diets [105-108].

\section{Medication}

Stimulant medication: (such as Methylphenidate, Dexamphetamine and Amoxetine) use has provoked much discussion about the long and short-term effects, and their use for young children. Many studies showing improved attention skills with use of these medications in ADHD [109]. They can be useful for the academic difficulties that can accompany ADHD $[110,111]$. Discussion on the long term effects are ongoing, though a minor decrease in height has been noted, medication use is associated with a reduced incidence of associated negative outcomes (substance abuse, prison, and domestic problems) $[112,113]$.

\section{Therapy}

\section{Behaviour therapy}

Therapy to modify the behaviour of children (such as cognitive behaviour therapy and social skills training), especially whose with ADHD, has been shown to have positive effects, either alone or in combination with medication, and is used to different degrees in many situations. It is time, expertise and personnel intensive, which may be a drawback [114-116]. 


\section{Specific exercise therapy}

Physical exercise has long been appreciated to have effects on cognitive function. In the same way that in sport people can be trained with repetition of basic functions to allow more complex functions to be concentrated on, programmes of repetitive exercises to improve basic function in areas of postural and eye movement control can allow more complex functions to be addressed. This has been formalized and discussed in numerous ways, with programmes of exercises that may be generalized or adapted to individual patients [117-121], though the outcome data, where available, has been criticised [122,123]. Other studies suggest that other movement programmes, such as Tai chi, may also be of benefit [124]. Exercise programmers to improve co-ordination and sensory processing may be beneficial.

\section{Auditory Therapy}

a) Music therapy has been developed [125], and has a role in the management of children with communication difficulties [126]. Though the science behind its effects are still not fully elucidated [127], there is evidence that musically trained people have altered cognitive-perceptive function on fMRI compared to those not musically trained [128-131], though whether this is because people with certain skill profiles take up music is not addressed.

b) Auditory integration therapy (AIT) (music modulated across the acoustic frequencies after assessment of the child's audiogram) may benefit children with APD, as well as learning and communication disorders, though it is still considered to be experimental due to lack of formal research evidence [132-134].

c) Auditory perceptual training: is a method of training a child's response to sound, usually delivered via computer programmes. It has shown some success in altering children's auditory responses, with suggestions that can help in many areas of learning difficulties as well as in post cochlea implant patients [135-138]. Training may improve auditory response times and neural plasticity is demonstrated after training [139,140].

\section{Visual Therapy}

a) Coloured lenses and overlays have been shown to alter the perception of text, increase reading speed, and to reduce migraines. This has been discussed as visual stress, Meares-Irlen syndrome and Scotopic sensitivity.

\section{Conclusion}

Children with auditory processing problems may have a wider range of learning problems, and may present to a variety of professionals. Poor processing of information in one area may co-exist with poor processing of information in other areas. Our clinical impression that poor processing skills are a factor in these children's problems is supported by current evidence. It is important to take a holistic approach to the assessment and management of these children. Many of the therapies being used have anecdotal reports of success but need more research evidence. Well designed studies to show which interventions work best for children with specific strength and weakness profiles will be vital to extend our knowledge in this area. The combined effect of a number of individually minor features of recognized conditions may have a compounding effect on the child. Despite having features of recognized conditions a child may be performing well above average academically in school, whilst not fulfilling their own potential. If the features are recognized and addressed they may perform better in the present competitive world, but changing teaching strategies may only be of benefit if child's problems acknowledged. It is essential that the strengths and weaknesses of each child be identified so that the parents and the educational institutions can provide appropriate help.

\section{References}

1. Baguley DM (2003) Hyperacusis. J R Soc Med 96(12): 582-585

2. William T Brandy, James M Lynn (1995) Audiologic Findings in Hyperacusic and Nonhyperacusic Subjects. American Journal of Audiology 4(1): 46-51.

3. Cacace AT, McFarland DJ (1998) Central auditory processing disorder in school-aged children: a critical review. J Speech Lang Hear Res 41(2): 355-373.

4. Rosen SM (2003) Auditory processing in dyslexia and specific language impairment: Is there a deficit? What is its nature? Does it explain anything? Journal of Phonetics 31(3): 509-527.

5. Bamiou DE, Musiek FE, Luxon LM (2001) Aetiology and clinical presentations of auditory processing disorders--a review. Arch Dis Child 85(5): 361-365.

6. Vanniasegaram I, Cohen M, Rosen S (2004) Evaluation of selected auditory tests in school-age children suspected of auditory processing disorders. Ear Hear 25(6): 586-597.

7. Geuze RH (2005) Postural control in children with developmental coordination disorder. Neural Plast 12(2-3): 183-196, discussion 263-272.

8. Geuze RH (2003) Static balance and developmental coordination disorder. Hum Mov Sci 22(4-5): 527-548.

9. Rochelle KS, Talcott JB (2006) Impaired balance in developmental dyslexia? A meta-analysis of the contending evidence. J Child Psychol Psychiatry 47(11): 1159-1166.

10. Stoodley CJ, Fawcett AJ, Nicolson RI, Stein JF (2005) Impaired balancing ability in dyslexic children. Exp Brain Res 167(3): 370-380.

11. Snowling MJ (2000) Dyslexia ( $2^{\text {nd }}$ edn), Blackwell, Oxford, UK.

12. Ram-Tsur R, Faust M, Caspi A, Gordon CR, Zivotofsky AZ (2006) Evidence for ocular motor deficits in developmental dyslexia: application of the double-step paradigm. Invest Ophthalmol Vis Sci 47(10): 4401-4409.

13. Holmberg K, Hjern A (2006) Health complaints in children with attention-deficit/hyperactivity disorder. Acta Paediatr 95(6): 664670 .

14. Doran SM, Van Dongen HP, Dinges DF (2001) Sustained attention performance during sleep deprivation: evidence of state instability. Arch Ital Biol 139(3): 253-267.

15. O'Hare A, Khalid S (2002) The association of abnormal cerebellar function in children with developmental coordination disorder and reading difficulties. Dyslexia 8(4): 234-248. 
16. Restuccia D, Della Marca G, Valeriani M, Leggio MG, Molinari M (2007) Cerebellar damage impairs detection of somatosensory input changes. A somatosensory mismatch-negativity study. Brain $130(\mathrm{Pt}$ 1): 276-287.

17. Snashall SE (1983) Vestibular function tests in children. J R Soc Med 76(7): 555-559.

18. Bucci MP, Brémond-Gignac D, Kapoula Z (2008) Poor binocular coordination of saccades in dyslexic children. Graefes Arch Clin Exp Ophthalmol 246(3): 417-428.

19. Callu D, Giannopulu I, Escolano S, Cusin F, Jacquier-Roux M, et al. (2005) Smooth pursuit eye movements are associated with phonological awareness in preschool children. Brain Cogn 58(2): 217-225.

20. Eden GF, Stein JF, Wood HM, Wood FB (1994) Differences in eye movements and reading problems in dyslexic and normal children. Vision Res 34(10): 1345-1358.

21. Bartel P, Offermeier W, Smith F, Becker P (2004) Attention and working memory in resident anaesthetists after night duty: group and individual effects. Occup Environ Med 61(2): 167-170.

22. Crawford SG, Kaplan BJ, Dewey D (2006) Effects of coexisting disorders on cognition and behavior in children with ADHD. J Atten Disord 10(2): 192-199.

23. Yardley L, Papo D, Bronstein A, Gresty M, Gardner M, et al. (2002) Attentional demands of continuously monitoring orientation using vestibular information. Neuropsychologia 40: 373-383.

24. Redfern MS, Furman JM, Jacob RG (2006) Visually induced postural sway in anxiety disorders. J Anxiety Disord 21(5): 704-716.

25. Jauregui-Renaud K, Yen Pik Sang F, Gresty MA, Bronstein AM (2007) Depersonalization/derealization symptoms and updating orientation in patients with vestibular disease. J Neurol Neurosurg Psychiatry 79(3): 276-283.

26. Winter DA, Patla AE, Prince F, Ishac M, Gielo-Perczak K (1998) Stiffness control of balance in quiet standing. J Neurophysiol 80(3): 1211-1221.

27. Ouchi Y, Okada H, Yoshikawa E, Nobezawa S, Futatsubashi M (1999) Brain activation during maintenance of standing postures in humans. Brain 122 (Pt 2): 329-338.

28. Karita K, Nakao M, Nishikitani M, Iwata T, Murata K, et al. (2006) Effect of overtime work and insufficient sleep on postural sway in information-technology workers. J Occup Health 48(1): 65-68.

29. Liu Y, Higuchi S, Motohashi Y (2001) Changes in postural sway during a period of sustained wakefulness in male adults. Occup Med (Lond) 51(8): 490-495.

30. Pline KM, Madigan ML, Nussbaum MA (2006) Influence of fatigue time and level on increases in postural sway. Ergonomics 49(15): 1639-1648.

31. Webster RI, Shevell MI (2004) Neurobiology of specific language impairment. J Child Neurol 19(7): 471-481.

32. Marton K, Schwartz RG (2003) Working memory capacity and language processes in children with specific language impairment. J Speech Lang Hear Res 46(5): 1138-1153.

33. Booth JR, Wood L, Lu D, Houk JC, Bitan T (2007) The role of the basal ganglia and cerebellum in language processing. Brain Res 1133(1): 136-144.

34. McAnally KI, Stein JF (1996) Auditory temporal coding in dyslexia. Proc Biol Sci 263(1373): 961-965.

35. Talcott JB, Witton C, McLean MF, Hansen PC, Rees A, et al. (2000)
Dynamic sensory sensitivity and children's word decoding skills. Proc Natl Acad Sci USA 97(6): 2952-2957.

36. Yap RL, van der Leij A (1994) Testing the automatization deficit hypothesis of dyslexia via a dual-task paradigm. J Learn Disabil 27(10): 660-665.

37. Clayton J (2000) Lost for words. New scientist 24: 99.

38. Gepner B, Mestre D (2002) Rapid visual-motion integration deficit in autism. Trends Cogn Sci 6(11): 455.

39. Stein J (2001) The magnocellular theory of developmental dyslexia. Dyslexia 7(1): 12-36.

40. Livingstone MS, Rosen GD, Drislane FW, Galaburda AM (1991) Physiological and anatomical evidence for a magnocellular defect in developmental dyslexia. Proc Natl Acad Sci U S A 88(18): 7943-7947.

41. Temple E, Deutsch GK, Poldrack RA, Miller SL, Tallal P, et al. (2003) Neural deficits in children with dyslexia ameliorated by behavioral remediation: evidence from functional MRI. Proc Natl Acad Sci U S A 100(5): 2860-2865.

42. Dolan RJ (1998) A cognitive affective role for the cerebellum. Brain 121 (Pt 4): 545-546.

43. Schmahmann JD, Sherman JC (1998) The cerebellar cognitive affective syndrome. Brain 121(Pt 4): 561-579.

44. Bower JM, Parsons LM (2003) Rethinking the "lesser brain". Sci Am 289(2): 50-57.

45. Ramnani N (2006) The primate cortico-cerebellar system: anatomy and function. Nat Rev Neurosci 7(7): 511-522.

46. Schatz, Hale S, Myerson J (1998) Cerebellar contribution to linguistic processing efficiency revealed by focal damage. J Int Neuropsychol Soc 4(5): 491-501.

47. Nicolson RI, Fawcett AJ, Dean P (2001) Developmental dyslexia: the cerebellar deficit hypothesis. Trends Neurosci 24(9): 508-511.

48. Brookes RL, Nicolson RI, Fawcett AJ (2007) Prisms throw light on developmental disorders. Neuropsychologia 45(8): 1921-1930.

49. Bares M, Lungu O, Liu T, Waechter T, Gomez CM, Ashe J (2007) Impaired predictive motor timing in patients with cerebellar disorders. Exp Brain Res 180(2): 355-365.

50. Turner BM, Paradiso S, Marvel CL, Pierson R, Boles Ponto LL, et al. (2007) The cerebellum and emotional experience. Neuropsychologia 45(6): 1331-1341.

51. Bishop, DVM, (2002) Cerebellar Abnormalities In Developmental Dyslexia: Cause, Correlate or Consequence? Cortex 38: 491-498.

52. ASHA (2005) (Central) auditory processing disorders: American Speech-Language-Hearing, USA.

53. Cacace AT, McFarland DJ (2005) The importance of modality specificity in diagnosing central auditory processing disorder. American Journal of Audiology 14(2): 112-123.

54. Musiek FE, Bellis TJ, Chermak GD (2005) Nonmodularity of the central auditory nervous system: implications for (central) auditory processing disorder. Am J Audiol 14(2): 128-138; discussion 143150 .

55. Katz J, Tillery KL (2005) Can central auditory processing tests resist supramodal influences? Am J Audiol 14(2): 124-147; discussion 143150.

56. Cacace AT, McFarland DJ (2005) Response to Katz and Tillery Musiek, Bellis, and Chermak and Rosen (2005) American Journal of Audiology 14(2): 143-150. 


\section{Global Journal of Otolaryngology}

57. McPhillips M, Jordan-Black JA (2007) Primary reflex persistence in children with reading difficulties (dyslexia): a cross-sectional study. Neuropsychologia 45(4): 748-754.

58. McPhillips M, Sheehy N (2004) Prevalence of persistent primary reflexes and motor problems in children with reading difficulties. Dyslexia 10(4): 316-338.

59. Brookes RL, Stirling J (2005) The cerebellar deficit hypothesis and dyslexic tendencies in a non-clinical sample. Dyslexia 11(3): 174185.

60. Stoodley CJ, Fawcett AJ, Nicolson RI, Stein JF (2006) Balancing and pointing tasks in dyslexic and control adults. Dyslexia 12(4): 276288.

61. Zolotor A, Mayer J, Hill J (2004) Clinical inquiries. Does a short symptom checklist accurately diagnose ADHD? J Fam Pract 53(5): 412-416.

62. Van Waelvelde H, Peersman W, Lenoir M, Smits Engelsman BC (2007) The reliability of the Movement Assessment Battery for Children for preschool children with mild to moderate motor impairment. Clin Rehabil 21(5): 465-470.

63. Arnold P, Canning D (1999) Does classroom amplification aid comprehension? Br J Audiol 33(3): 171-178.

64. Cohen W, Hodson A, O’Hare A, Boyle J, Durrani T, et al. (2005) Effects of computer-based intervention using acoustically modified speech (Fast ForWord-Languageâ) in receptive language impairment: Outcomes from a randomised controlled trial. J Speech Lang Hear Res 48: 715-729.

65. Azrin NH, Ehle CT, Beaumont AL (2006) Physical exercise as a reinforcer to promote calmness of an ADHD child. Behav Modif 30(5): 564-570

66. Tantillo M, Kesick CM, Hynd GW, Dishman RK (2002) The effects of exercise on children with attention-deficit hyperactivity disorder Med Sci Sports Exerc 34(2): 203-212.

67. Dwyer T, Sallis JF, Blizzard L, Lazarus R, Dean K (2001) Relation of Academic Performance to Physical Activity and Fitness in Children. PES 13: 225-237.

68. Sallis JF, McKenzie TL, Kolody B, Lewis M, Marshall S, et al. (1999) Effects of health-related physical education on academic achievement: project SPARK. Res Q Exerc Sport 70(2): 127-134.

69. Putnam, Stephen C, Tette, Joseph, Wendt, et al. (2004) Exercise: A Prescription for At-Risk Students. Journal of Physical Education Recreation and Dance JOPERD 75(9): 25-28.

70. Richardson AJ (2006) Omega-3 fatty acids in ADHD and related neurodevelopmental disorders. Int Rev Psychiatry 18(2): 155-172.

71. Stevens L, Zhang W, Peck L, Kuczek T, Grevstad N, et al. (2003) EFA supplementation in children with inattention, hyperactivity, and other disruptive behaviors. Lipids 38(10): 1007-1021.

72. Richardson AJ, Montgomery P (2005) The Oxford-Durham study: a randomized, controlled trial of dietary supplementation with fatty acids in children with developmental coordination disorder Pediatrics 115(5): 1360-1366.

73. Freeman MP, Hibbeln JR, Wisner KL, Davis JM, Mischoulon D, et al (2007) Omega-3 fatty acids: evidence basis for treatment and future research in psychiatry. J Clin Psychiatry 67(12): 1954-1967.

74. Stordy BJ (2000) Dark adaptation, motor skills, docosahexaenoic acid, and dyslexia. Am J Clin Nutr 71(1 Suppl): 323S-326S

75. Carter CM, Urbanowicz M, Hemsley R, Mantilla L, Strobel S, et al (1993) Effects of a few food diet in attention deficit disorder. Arch Dis Child 69(5): 564-568.
76. Rowe KS (1988) Synthetic food colourings and 'hyperactivity': a double-blind crossover study. Aust Paediatr J 24(2): 143-147.

77. Bateman B, Warner JO, Hutchinson E, Dean T, Rowlandson P, et al (2004) The effects of a double blind, placebo controlled, artificial food colourings and benzoate preservative challenge on hyperactivity in a general population sample of preschool children. Arch Dis Child 89(6): 506-511

78. McCann D, Barrett A, Cooper A, Crumpler D, Dalen L, et al. (2007) Food additives and hyperactive behaviour in 3-year-old and 8/9-year-old children in the community: a randomised, double-blinded, placebocontrolled trial. Lancet 370(9598): 1560-1567.

79. Hood J, Baird G, Rankin PM, Isaacs E (2005) Immediate effects of methylphenidate on cognitive attention skills of children with attention-deficit-hyperactivity disorder. Dev Med Child Neurol 47(6): 408-414

80. MTA Cooperative Group (2004) National Institute of Mental Health Multimodal Treatment Study of ADHD follow-up: 24-month outcomes of treatment strategies for attention-deficit/hyperactivity disorder. Pediatrics 113(4): 754-761.

81. Tucha O, Mecklinger L, Laufkotter R, Klein HE, Walitza S, et al. (2006) Methylphenidate-induced improvements of various measures of attention in adults with attention deficit hyperactivity disorder. J Neural Transm 113(10): 1575-1592.

82. Faraone SV, Upadhyaya HP (2007) The effect of stimulant treatment for ADHD on later substance abuse and the potential for medication misuse, abuse, and diversion. J Clin Psychiatry 68(11): e28.

83. Swanson JM, Elliott GR, Greenhill LL, Wigal T, Arnold LE, et al. (2007) Effects of stimulant medication on growth rates across 3 years in the MTA follow-up. J Am Acad Child Adolesc Psychiatry 46(8): 10151027.

84. Van den Hoofdakker BJ, van der Veen-Mulders L, Sytema S, Emmelkamp PM, Minderaa RB, et al. (2007) Effectiveness of behavioral parent training for children with ADHD in routine clinical practice: a randomized controlled study. J Am Acad Child Adolesc Psychiatry 46(10): 1263-1271.

85. Pelham WE Jr, Fabiano GA (2000) Behavior modification. Child Adolesc Psychiatr Clin N Am 9(3): 671-688.

86. Foster EM, Jensen PS, Schlander M, Pelham WE Jr, Hechtman L, et al. (2007) Treatment for ADHD: is more complex treatment costeffective for more complex cases? Health Serv Res 42(1 Pt 1): 165182.

87. Ayres AJ (1979) Sensory integration and the child. Western Psychological Press, USA.

88. Reynolds D, Nicolson RI, Hambly H (2003) Evaluation of an exercisebased treatment for children with reading difficulties. Dyslexia 9(1): 48-71.

89. Belgau F, Belgau BV (1982) Learning Breakthrough Program Balermetrics Port Angeles WA, USA.

90. Goddard-Blythe S (2002) Reflexes, Learning and Behaviour Hawthorn Press, England.

91. Sifft JM, Khalsa GC (1991) Effect of educational kinesiology upon simple response times and choice response times. Percept Mot Skills 73(3 Pt 1): 1011-1015.

92. Bishop DV (2007) Curing dyslexia and attention-deficit hyperactivity disorder by training motor co-ordination: miracle or myth? J Paediatr Child Health 43(10): 653-655.

93. Rack JP, Snowling MJ, Hulme C, Gibbs S (2007) No evidence that an exercise-based treatment programme (DDAT) has specific benefits 


\section{Global Journal of Otolaryngology}

for children with reading difficulties. Dyslexia 13(2): 97-104, discussion 105-109.

94. Tsang WW, Hui-Chan CW (2006) Standing balance after vestibular stimulation in Tai Chi-practicing and nonpracticing healthy older adults. Arch Phys Med Rehabil 87(4): 546-553.

95. Kim Y (2004) The early beginnings of Nordoff-Robbins music therapy. J Music Ther Winter 41(4): 321-339.

96. Aldridge D (1989) Music, communication and medicine: discussion paper. J R Soc Med 82(12): 743-746.

97. Hillecke T, Nickel A, Bolay HV (2005) Scientific perspectives on music therapy. Ann N Y Acad Sci 1060: 271-282.

98. Schlaug G, Norton A, Overy K, Winner E (2005) Effects of music training on the child's brain and cognitive development. Ann N Y Acad Sci 1060: 219-223.

99. Parsons LM (2001) Exploring the functional neuroanatomy of music performance, perception, and comprehension. Ann N Y Acad Sci 930: 211-231.

100. Brown J, Sherrill C, Gench B (1981) Effects of an integrated physical education/music program in changing early childhood perceptualmotor performance. Percept Mot Skills 53(1): 151-154.

101. Yencer KA (1998) The Effects of Auditory Integration Training for Children With Central Auditory Processing Disorders. American Journal of Audiology 7: 32-44.

102. Stephen M Edelson, Bernard Rimland (2001) The Efficacy of Auditory Integration Training. Summaries and Critiques of 28 Reports, p. 21.

103. Kozlowski L, Kroupnik M, Kochen AP, Zeigelboim BS (2004) Auditory integration training: "miracle" in the treatment for autism? Rev Bras Psiquiatr 26(3): 214-215.

104. Amitay S, Irwin A, Hawkey DJ, Cowan JA, Moore DR (2006) A comparison of adaptive procedures for rapid and reliable threshold assessment and training in naive listeners. J Acoust Soc Am 119(3): $1616-1625$

105. Amitay S, Hawkey DJ, Moore DR (2005) Auditory frequency discrimination learning is affected by stimulus variability. Percept Psychophys 67(4): 691-698.

106. Warrier CM, Johnson KL, Hayes EA, Nicol T, Kraus N (2004) Learning impaired children exhibit timing deficits and training-related improvements in auditory cortical responses to speech in noise. Exp Brain Res 157(4): 431-441.

107. Fu QJ, Galvin JJ (2007) Perceptual learning and auditory training in cochlear implant recipients. Trends Amplif 11(3): 193-205.

108. Russo NM, Nicol TG, Zecker SG, Hayes EA, Kraus N (2005) Auditory training improves neural timing in the human brainstem. Behav Brain Res 156(1): 95-103.

109. Hayes EA, Warrier CM, Nicol TG, Zecker SG, Kraus N (2003) Neural plasticity following auditory training in children with learning problems. Clin Neurophysiol 114(4): 673-684.

110. Gibbs J, Appleton J, Appleton R (2007) Dyspraxia or developmental coordination disorder? Unravelling the enigma. Arch Dis Child 92(6): 534-539.

111. Kingsley Whitmore, Hillary Hart, Guy Willems (1999) A Neurodevelopmental Approach to Specific Learning Disorders. Clinics in Developmental Medicine 145 New York, Cambridge University Press, USA.

112. Sharma M, Purdy SC, Newall P, Wheldall K, Beaman R, et al. (2006) Electrophysiological and behavioral evidence of auditory processing deficits in children with reading disorder. Clin Neurophysiol 117(5): 1130-1144.
113. Gomez R, Condon M (1999) Central auditory processing ability in children with ADHD with and without learning disabilities. J Learn Disabil 32(2): 150-158.

114. Weiler MD, Bernstein JH, Bellinger D, Waber DP (2002) Information processing deficits in children with attention-deficit/hyperactivity disorder, inattentive type, and children with reading disability. J Learn Disabil 35(5): 448-461.

115. King WM, Lombardino LJ, Crandell CC, Leonard CM (2003) Comorbid auditory processing disorder in developmental dyslexia. Ear Hear 24(5): 448-456.

116. Dewey D, Cantell M, Crawford SG (2007) Motor and gestural performance in children with autism spectrum disorders, developmental coordination disorder, and/or attention deficit hyperactivity disorder. J Int Neuropsychol Soc 13(2): 246-256.

117. Piek JP, Dyck MJ (2004) Sensory-motor deficits in children with developmental coordination disorder, attention deficit hyperactivity disorder and autistic disorder. Hum Mov Sci 23(3-4): 475-488.

118. Rosenhall U, Nordin V, Sandström M, Ahlsén G, Gillberg C (1999] Autism and hearing loss. J Autism Dev Disord 29(5): 349-357.

119. Tseng MH, Howe TH, Chuang IC, Hsieh CL (2007) Co-occurrence of problems in activity level, attention, psychosocial adjustment, reading and writing in children with developmental coordination disorder. Int J Rehabil Res 30(4): 327-332.

120. Guralnik O, Giesbrecht T, Knutelska M, Sirroff B, Simeon D (2007) Cognitive functioning in depersonalization disorder. J Nerv Ment Dis 195(12): 983-988.

121. Riccio CA, Hynd GW, Cohen MJ, Hall J, Molt L (1994) Comorbidity of central auditory processing disorder and attention-deficit hyperactivity disorder. J Am Acad Child Adolesc Psychiatry 33(6): 849-857.

122. Denckla, PANESS (1974) Physical and Neurological Exam for Subtle Signs, Developmental Medicine and Child Neurology 16(6): 729-741.

123. Larson JC, Mostofsky SH, Goldberg MC, Cutting LE, Denckla MB, et al. (2007) Effects of gender and age on motor exam in typically developing children. Dev Neuropsychol 32(1): 543-562.

124. Fellick JM, Thomson AP, Sills J, Hart CA (2001) Neurological soft signs in mainstream pupils. Arch Dis Child 85: 371-374.

125. Dazzan P, Morgan KD, Orr KG, Hutchinson G, Chitnis X, et al. (2004) The structural brain correlates of neurological soft signs in AESOP first-episode psychoses study. Brain 127(Pt 1): 143-153.

126. Holden E Wayne, Tarnowski KJ, Prinz RJ (1982) Reliability of Neurological Soft Signs in Children: Reevaluation of the PANESS. Journal of Abnormal Child Psychology 10(2): 163-172.

127. Camp et al. (1978) Clinical usefulness of the NIMH physical and neurological examination for soft signs. Am J Psychiatry 135: 362364.

128. Larson JC, Mostofsky SH, Goldberg MC, Cutting LE, Denckla MB, et al. (2007) Effects of gender and age on motor exam in typically developing children. Dev Neuropsychol 32(1): 543-562.

129. Dziuk MA, Gidley Larson JC, Apostu A, Mahone EM, Denckla MB, et al. (2007) Dyspraxia in autism: association with motor, social, and communicative deficits. Dev Med Child Neurol 49(10): 734-739.

130. Dawes P, Bishop DV (2007) The SCAN-C in testing for auditory processing disorder in a sample of British children. Int J Audiol 46(12): 780-786.

131. Cunningham J, Nicol T, Zecker SG, Bradlow A, Kraus N (2001) Neurobiologic responses to speech in noise in children with learning problems: deficits and strategies for improvement. Clin Neurophysiol 112(5): 758-767. 
132. Fawcett A, Nicolson R (2004) Dyslexia Screening Test Junior (DST-J). Pearson, USA.

133. Miles TR (1997) The Bangor Dyslexia Test LDA, Cambs revised.

134. Kast M, Meyer M, Vögeli C, Gross M, Jäncke L (2007) Computer-based multisensory learning in children with developmental dyslexia. Restor Neurol Neurosci 25(3-4): 355-369.

135. Willcutt EG, Pennington BF, Smith SD, Cardon LR, Gayan J, et al. (2002) Quantitative trait locus for reading disability on chromosome $6 \mathrm{p}$ is pleiotropic for attention-deficit/hyperactivity disorder. Am J Med Genet 114: 260-268.

136. Stevenson J, Langley K, Pay H, Payton A, Worthington J, et al. (2005) Attention deficit hyperactivity disorder with reading disabilities: preliminary genetic findings on the involvement of the ADRA2A gene. J Child Psychol Psychiatry 46: 1081-1088.

137. Morell RJ, Brewer CC, Ge D, Snieder H, Zalewski CK, et al. (2007) A twin study of auditory processing indicates that dichotic listening ability is a strongly heritable trait. Hum Genet 122(1): 103-111.

138. Gibson CJ, Gruen JR (2008) The human lexinome: Genes of language and reading. J Commun Disord 41(5): 409-420.

139. Caylak E (2007) A review of association and linkage studies for genetical analyses of learning disorders. Am J Med Genet B Neuropsychiatr Genet 144B (7): 923-943.

140. Gaser C, Schlaug G (2003) Brain structures differ between musicians and non-musicians. J Neurosci. 23(27): 9240-9245.

\begin{tabular}{l} 
Your next submission with Juniper Publishers \\
will reach you the below assets \\
- Quality Editorial service \\
- Swift Peer Review \\
- Reprints availability \\
- E-prints Service \\
- Manuscript Podcast for convenient understanding \\
- Global attainment for your research \\
- Manuscript accessibility in different formats \\
( Pdf, E-pub, Full Text, Audio) \\
- Unceasing customer service \\
Track the below URL for one-step submission \\
https://juniperpublishers.com/online-submission.php \\
\hline
\end{tabular}

